\title{
THE ROLE OF SHIELDING GAS ON MECHANICAL, METALLURGICAL AND CORROSION PROPERTIES OF CORTEN STEEL WELDED JOINTS OF RAILWAY COACHES USING GMAW
}

\author{
Byju John', Sathiya Paulraj², Jolly Mathew ${ }^{3}$ \\ 1 Centre for Excellence in Corrosion and Surface Engineering (CECASE), National Institute of Technology, \\ Tiruchirappalli 620 015, Tamilnadu, India \\ 2 CECASE \& Department of Production Engineering, National Institute of Technology, Tiruchirappalli 620015 , \\ Tamilnadu, India, e-mail: psathiya@nitt.edu \\ 3 Central Workshops, Southern Railway, Tiruchirappalli 620 004, Tamilnadu, India
}

Received: 2016.08.16

Accepted: 2016.10.08

Published: 2016.12.01

\begin{abstract}
This analysis lays emphasis on finding a suitable combination of shielding gas for welding underframe members such as sole bar of Railway Coaches made of corten steel; for improved mechanical, metallurgical and corrosion properties of welds using copper coated solid MIG/MAG welding filler wire size $1.2 \mathrm{~mm}$ conforming to AWS/SFA 5.18 ER $70 \mathrm{~S}$ in Semi-automatic GMAW process. Solid filler wire is preferred by welders due to less fumes, practically no slag and easy manipulation of welding torch with smooth wire flow during corrosion repair attention, when compared to Flux cored wire. Three joints using Gas metal arc welding (GMAW) with shielding gases viz., Pure $\mathrm{CO}_{2},\left(80 \% \mathrm{Ar}-20 \% \mathrm{CO}_{2}\right)$ and $\left(90 \% \mathrm{Ar}-10 \% \mathrm{CO}_{2}\right)$ were made from test pieces cut from Sole bar material of Railway Coach. Study of Mechanical properties such as tensile strength, hardness and toughness revealed that welded joint made using shielding gas $\left(80 \% \mathrm{Ar}-20 \% \mathrm{CO}_{2}\right)$ has better Mechanical properties compared to the other two shielding gases and comparable to that of Parent metal. Type of Shielding gas used has influence on the chemical composition and macro \& micro structures. The Tafel extrapolation study of freshly ground samples in $3.5 \% \mathrm{NaCl}$ solution revealed that the welded joint made using shielding gas $(80 \%$ $\mathrm{Ar}-20 \% \mathrm{CO}_{2}$ ) has also better corrosion resistance which is comparable to the Parent metal as well as similar commercial steels.
\end{abstract}

Keywords: gas metal arc welding, shielding gas, corrosion, weld microstructure, corten steel.

\section{INTRODUCTION}

Welding is one of the main activities for the corrosion repair attention of Railway Coaches during periodical overhauling $(\mathrm{POH})$. With the adoption of light gauge steel sheets and plates in the manufacture of Railway Coaches for weight reduction and also due to their exposure to sun light, moisture, industrial and atmospheric pollution, the life of the Coaches are affected due to corrosion, which is the natural reaction(electrochemical reaction) with the release of energy and is the process of metal returning to Ore. To increase the longevity of the life of the Coaches, the corrosion should be minimized by taking suitable steps at the maintenance stages.

Railway coaches which are constructed using low alloy high yield strength corten steel, generally require their first corrosion repair after 9 to 11 years and does not require corrosion repairs at the same location for a further period of 6 to 7 years. But in view of factors such as non-avail- 
ability of materials of the prescribed quality and specification variations in quality of workmanship and climatic and service conditions from Railway to Railway, it is difficult to predict the period for repair with any degree of accuracy [8]. It will, therefore, be necessary that on subsequent despatch of these coaches to workshops for Periodical Overhauling $(\mathrm{POH})$ which is now fixed as once every 18 months, all coaches irrespective of age and the degree of attention given in the previous POHs should be subjected to a thorough examination. During $\mathrm{POH}$, the corroded portions of structural members such as sole-bar are gas cut and new parts are welded in position.

This analysis is carried out to find a suitable combination of shielding gases for improved mechanical, metallurgical and corrosion properties of welds during corrosion repair using semiautomatic GMAW process with copper coated solid MIG/MAG welding filler wire size $1.2 \mathrm{~mm}$ conforming to AWS/SFA 5.18 ER 70 S. The solid wire is found to have a good operator appeal due to less noxious fumes, smooth wire flow and easy manipulation of weld Torch for corrosion repair activities in coaches at various locations in Semiautomatic GMAW process and also economical due to low cost compared to Flux cored wire.

\section{LITERATURE SURVEY}

High productivity, applicability for a wide range of base metal thickness in all welding positions, and adoptability to automation are characteristics of Gas metal arc welding (GMAW) process [14]. GMAW process has become popular because of its high quality welded joints that can be obtained at relatively low cost [5], and its considerable potential for automation [7]. The primary function of the shielding gas is to protect the molten metal from atmospheric gases as the weld pool is being formed. The gas also promotes a stable arc and uniform metal transfer. The quality, efficiency, and overall operating acceptance of the welding operation are strongly dependent on the shielding gas, since it dominates the mode of the metal transfer [7]. The shielding gas not only affects the properties of the weld but also determines its shape and penetration pattern. During welding, the shielding gas also interacts with the welding wire determining the strength, toughness and corrosion resistance of weld deposits. The shielding gas also affects the residual contents of hydrogen, nitrogen and oxygen dissolved in the weld metal [18].

The low alloy high yield strength corten steel to IR Specification No. M-41 [10], used in the construction of Indian Railway Coaches, falls in the category of weathering steels [13,21] and it is similar to commercially available steels such as SAILCOR grade steel produced by Bokaro Steel Plant,SAIL, India and patented CORTEN steel USA [6]. They contain small amounts of alloying elements such as Chromium, Nickel, Copper and Phosphorus for mitigating atmospheric corrosion and solid-solution strengthening. The enhanced corrosion resistance of Corten Steel is due to the formation of a dense and well-adhering corrosion product layer known as the patina [13] which protects the steel from corrosive environment. Besides possessing greater mechanical strength and corrosion resistance than mild steel or plain carbon steel, the patina is also valued for its attractive appearance and self-healing abilities.

It is sometimes difficult to determine why welds corrode and many factors starting from weld design are implicated. Weldments can experience all the classical forms of corrosion, but they are particularly susceptible to those affected by variations in microstructure and composition [4]. Corrosion resistance can usually be maintained in the welded condition by balancing alloy compositions to inhibit certain precipitation reactions, by shielding molten and hot metal surfaces from reactive gases in the weld environment, by removing chromium-enriched oxides and chromium-depleted base metal from thermally discoloured (heat tinted) surfaces, and by choosing the proper welding parameters. Weldments exhibit special microstructural features that need to be recognized and understood in order to predict acceptable corrosion service life of welded structures. Weldments inherently possess compositional and microstructural heterogeneities, which can be classified by dimensional scale. On the largest scale, a weldment consists of a transition from wrought base metal through an HAZ and into solidified weld metal and includes five microstructurally distinct regions normally identified as the fusion zone, the unmixed region, the partially melted region, the HAZ, and the unaffected base metal. On a fine scale, microstructural gradients exist within the HAZ due to different time-temperature cycles experienced by each element of material. Gradients on a similar scale exist within solidified multi-pass weld metal due 
Table 1. Chemical composition requirement of parent metal and filler wire (in weight \%)

\begin{tabular}{|l|c|c|c|c|c|c|c|c|c|}
\hline & $\mathbf{C}$ & $\mathbf{S i}$ & $\mathbf{M n}$ & $\mathbf{N i}$ & $\mathbf{C u}$ & $\mathbf{C r}$ & $\mathbf{S}$ & $\mathbf{P}$ & $\begin{array}{c}\text { Incidental Elements } \\
\mathbf{( 0 . 1 5} \text { max })\end{array}$ \\
\hline $\begin{array}{l}\text { Parent } \\
\text { metal }\end{array}$ & $\begin{array}{c}0.10 \\
\text { max. }\end{array}$ & $\begin{array}{c}0.28 \\
\text { to } 0.72\end{array}$ & $\begin{array}{c}0.25 \\
\text { to } 0.45\end{array}$ & $\begin{array}{c}0.20 \\
\text { to } 0.47\end{array}$ & $\begin{array}{c}0.30 \\
\text { to } 0.60\end{array}$ & $\begin{array}{c}0.35 \\
\text { to } 0.60\end{array}$ & $\begin{array}{c}0.03 \\
\text { max. }\end{array}$ & $\begin{array}{c}0.075 \\
\text { to } 0.140\end{array}$ & $\begin{array}{c}\text { Mo }=0.05 \mathrm{max} \\
\mathrm{V}=0.05 \mathrm{max} \\
\mathrm{Al}=0.08 \mathrm{max} \\
\mathrm{Nb}=0.04 \mathrm{max}\end{array}$ \\
\hline Filler wire & $\begin{array}{c}0.07 \\
\text { to } 0.15\end{array}$ & $\begin{array}{c}0.80 \\
\text { to } 1.15\end{array}$ & $\begin{array}{c}1.40 \\
\text { to } 1.85\end{array}$ & -- & $\begin{array}{c}0.2 \\
\text { to } 0.4\end{array}$ & -- & $\begin{array}{c}0.025 \\
\text { max. }\end{array}$ & $\begin{array}{c}0.025 \\
\text { max. }\end{array}$ & \\
\hline
\end{tabular}

Table 2. Mechanical property requirement of parent metal and filler wire

\begin{tabular}{|l|c|c|}
\hline Mechanical property & Parent Metal & Filler wire \\
\hline Tensile strength(MPa) & 480 min. & 510 \\
\hline Yield strength(MPa) & 340 min. & 350 \\
\hline Elongation (\%) & $22 \%$ min. & $26 \%$ \\
\hline
\end{tabular}

to bead-to-bead variations in thermal experience. Compositional gradients on the scale of a few microns, referred to as microsegregation, exist within individual weld beads due to segregation of major and trace elements during solidification.

\section{MATERIALS AND METHODS}

The sample pieces of Parent metal for experiment were made ready from the cut pieces of new Sole bar material conforming to corten steel to Indian Railway Standard, IRS M41/97 [10]. The filler wire used for the welding of three test pieces was Copper coated solid MIG/MAG wire conforming to AWS/SFA 5.18 ER $70 \mathrm{~S}$ with 1.2 $\mathrm{mm}$ nominal diameter. The chemical composition and mechanical property requirements of both parent metal and filler wire are shown in Table 1 and Table 2 respectively.

Semi-automatic GMAW process with combinations of argon ( $\mathrm{Ar})$ and carbon dioxide $\left(\mathrm{CO}_{2}\right)$ as shielding gas was used in this study. The welded specimens were subjected to test and analysis to find out the Mechanical, metallurgical and corrosion properties to arrive at the most appropriate shielding gas.

\section{EXPERIMENTAL WORK}

Pure carbon dioxide $\left(\mathrm{CO}_{2}\right)$ and combinations of argon (Ar) and $\mathrm{CO}_{2}$ were used throughout this study. They meet the requirements of ASME SFA
5.32 [1] and have the compositions: (1) Pure $\mathrm{CO}_{2}$, (2) $80 \% \mathrm{Ar}-20 \% \mathrm{CO}_{2}$, (3) $90 \% \mathrm{Ar}-10 \% \mathrm{CO}_{2}$. The experimental work setup is shown in Figure 1, thus to obtain good actual heat input (HI); electric cables of arc data monitor III device were precisely fitted according to the manual user of the device especially to the contact tube and workpiece to minimize the losses in the generated $\mathrm{HI}$ and to obtain high arc efficiency for each shielding gas. On the other hand, for the theoretical HI the welding machine was precisely programmed to reduce the losses in the resulted HI.

The optimum welding conditions were selected as shown in table 3 and complete weld joints were accomplished using plates of $5 \mathrm{~mm}$ in thickness with dimensions $130 \mathrm{~mm}$ (length) $\times 125 \mathrm{~mm}$ (width) for each composition of shielding gas as shown in Figure 2. Each plate was mechanically bevelled to an angle of $30^{\circ}$ to form a single $\mathrm{V}$ butt groove joint with $1-3 \mathrm{~mm}$ root gap opening to study the effect of shielding gas compositions

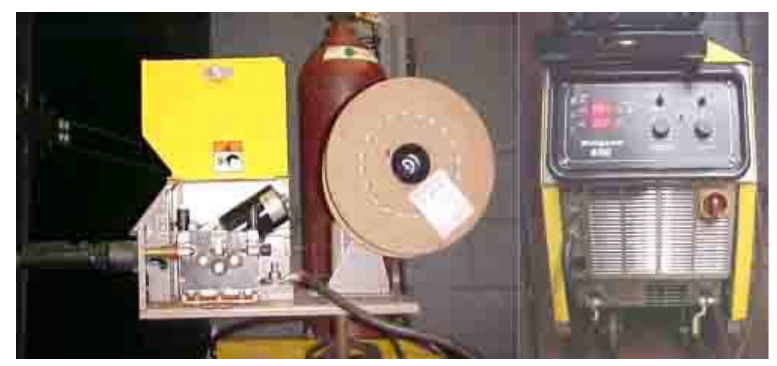

Fig. 1. Experimental work setup

Table 3. Welding conditions/Welding parameters

\begin{tabular}{|l|c|}
\hline Current & $220 \mathrm{Amps}$ \\
\hline Voltage & $24 \mathrm{~V}$ \\
\hline Gas flow rate & $15 \mathrm{Lpm}$ \\
\hline Welding speed & $35 \mathrm{~mm} / \mathrm{min}$ \\
\hline Coil feed rate & $80 \mathrm{~mm} / \mathrm{min}$ \\
\hline Standoff distance & 15 to $18 \mathrm{~mm}$ \\
\hline
\end{tabular}




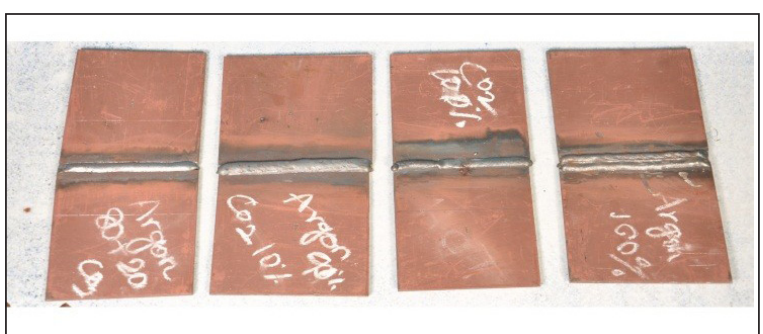

Fig. 2. Welded Joints

on both mechanical, metallurgical and corrosion properties of the weldments.

Required Specimens were prepared from the welded joints using band saw, machining, grinding and polishing for the tests and analysis to find out the Mechanical, metallurgical and corrosion properties. The specimens were marked as 1 for pure $\mathrm{CO}_{2} 2$ for $\left(80 \% \mathrm{Ar}-20 \% \mathrm{CO}_{2}\right)$ and 3 for $\left(90 \% \mathrm{Ar}-10 \% \mathrm{CO}_{2}\right)$ and analysed in Atlantisoptical emission spectrometer and the chemical composition of parent metal and weld metal obtained are given in Table 4. Chemical composition of parent metal is found conforming to the requirement as per Table 1 .

Tests for mechanical properties such as Tensile strength and Impact strength were carried out in FIE make Universal Testing Machine,UTE-60 and Charpy impact test machine Model: IT 30 respectively. Transverse tensile and impact tests were carried out with the weld centerline perpendicular to specimen longitudinal axis as shown in Figure 3 and Figure 4 respectively. Tensile specimen dimensions were according to ASME (IX) [2],while impact specimen dimensions were

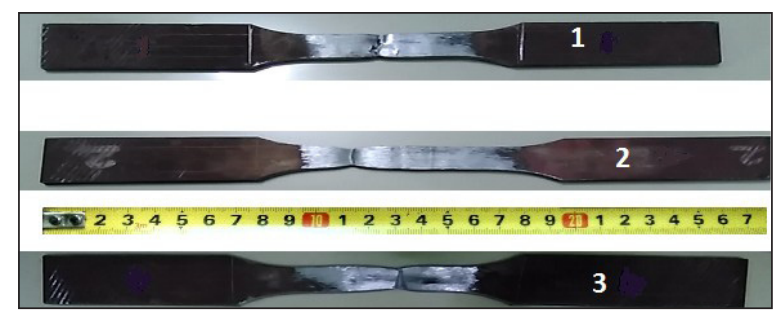

Fig. 3. Specimens after Tensile Test
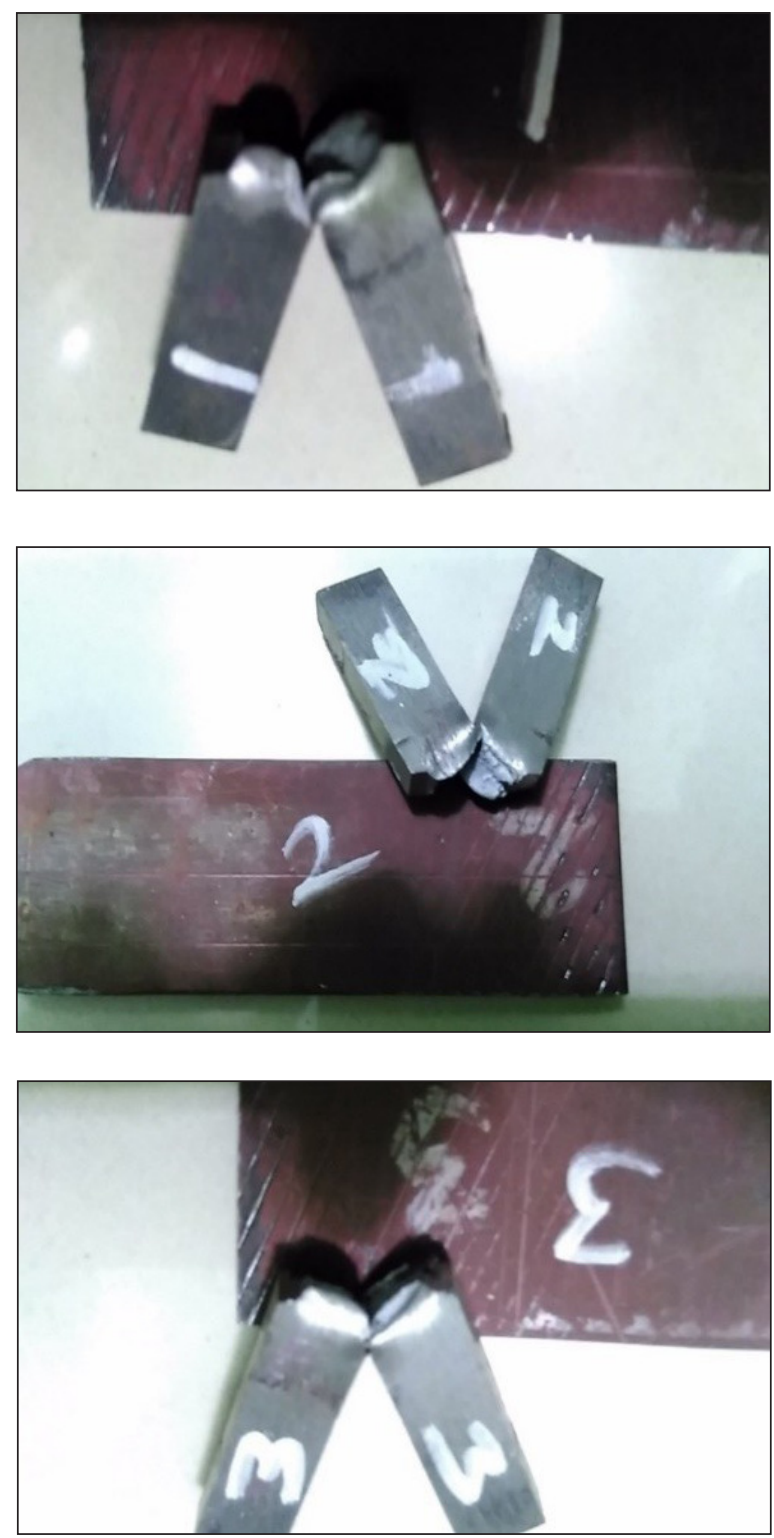

Fig. 4. Specimens after Charpy Impact test

$10 \times 5 \times 55 \mathrm{~mm}$ long according to ASME (II) [3]. Vickers hardness tests were also carried out using a load of $10 \mathrm{Kgf}$.

Metallographic examinations including macro and microstructure were carried out to identify the phases in both weld metal and heat affected zone using optical microscope. Examination of the fracture surfaces of impact speci-

Table 4. Chemical composition of parent metal and weld metal (in weight \%)

\begin{tabular}{|l|c|c|c|c|c|c|c|c|c|c|}
\hline & $\mathbf{F e}$ & $\mathbf{C}$ & $\mathbf{S i}$ & $\mathbf{M n}$ & $\mathbf{N i}$ & $\mathbf{C u}$ & $\mathbf{C r}$ & $\mathbf{S}$ & $\mathbf{P}$ & $\mathbf{N b}$ \\
\hline Parent metal & 98.238 & 0.097 & 0.31 & 0.34 & 0.21 & 0.30 & 0.41 & 0.02 & 0.075 & -- \\
\hline Weld Metal 1 & 97.972 & 0.069 & 0.604 & 1.009 & 0.068 & 0.123 & 0.087 & 0.019 & 0.032 & 0.017 \\
\hline Weld Metal 2 & 97.969 & 0.069 & 0.542 & 1.076 & 0.073 & 0.122 & 0.078 & 0.024 & 0.024 & 0.023 \\
\hline Weld Metal 3 & 97.703 & 0.076 & 0.647 & 1.132 & 0.092 & 0.149 & 0.132 & 0.013 & 0.025 & 0.031 \\
\hline
\end{tabular}




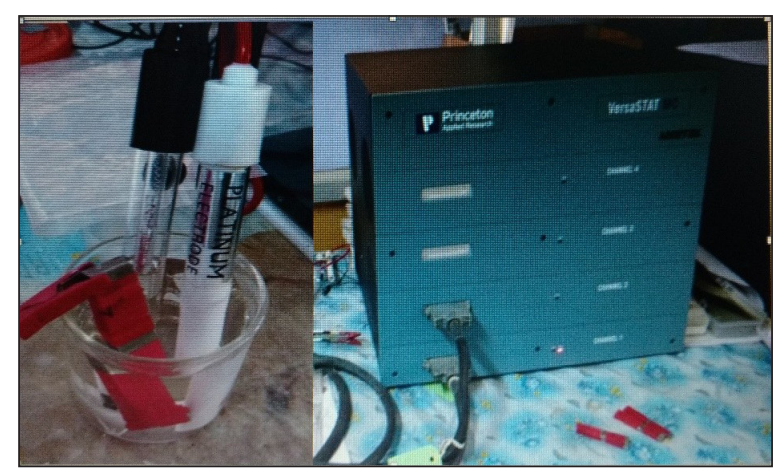

Fig. 5. Potentiodynamic polarisation measurement

mens and tensile specimens were carried out using Scanning Electron Microscope (SEM) and EDAS. Image analysis was carried out to estimate the area percent of the different phases of microstructures of complete joined weldments using image analyser software with metallurgical microscope.

Tafel extrapolation study using potentiometric polarisation technique was conducted to analyse the corrosion potential of the welds using Equipment-Princeton Applied research (Fig. 5) [16].

\section{RESULTS AND DISCUSSIONS}

Three test piece welds were carried out by using copper coated solid MIG/MAG wire conforming to AWS/SFA 5.18 ER70 S with $1.2 \mathrm{~mm}$ nominal diameter and the selected three shielding gases; (1) pure $\mathrm{CO}_{2}$, (2) $80 \% \mathrm{Ar}-20 \% \mathrm{CO}_{2}$ and (3) $90 \% \mathrm{Ar}-10 \% \mathrm{CO}_{2}$, by using approximately the same heat input and controlling the welding parameters.

\section{Effect of the different shielding gas compositions on macrostructure}

The macrographs indicated good penetration for all welds but non-uniform side wall fusion for specimen 1 and specimen 3 as shown in Figure 6. In the case of $\left(90 \% \mathrm{Ar}-10 \% \mathrm{CO}_{2}\right)$ composition (specimen 3), less heat input caused non-uniform side wall fusion. (80\% $\mathrm{Ar}$ $-20 \% \mathrm{CO}_{2}$ ) weld (specimen 2) shows a more uniform penetration of weld and uniform weld bead and optimum deposition rate. High rate of oxidation was caused by $\mathrm{CO}_{2}$ gas at weld temperature and hence irregular fusion of base metal (specimen 1) in case of pure $\mathrm{CO}_{2}$ shielding gas is observed.
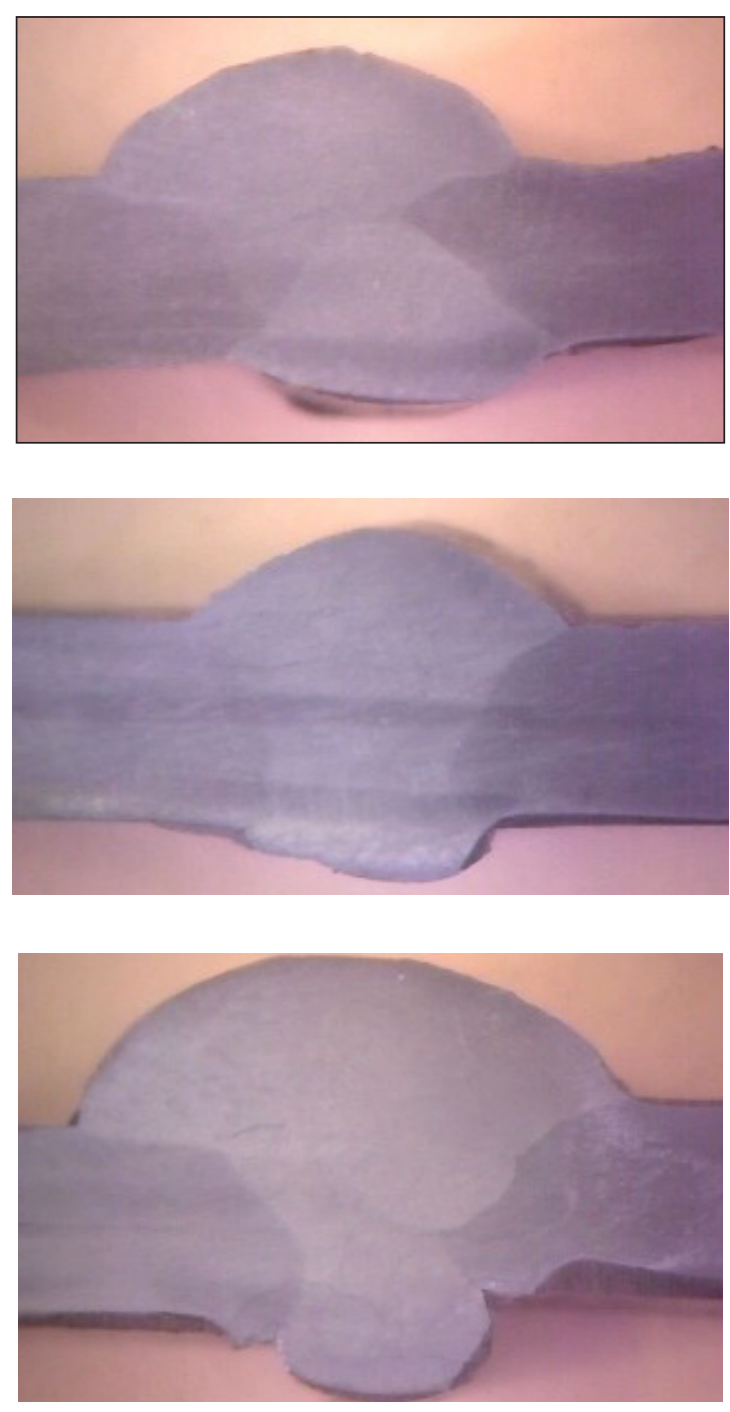

Fig. 6. Bead profile of the joints

\section{Effect of the different shielding gas compositions on weld metal microstructure}

The microstructure of parent metal (PM), heat affected zone (HAZ) and weld metal (WM) of investigated weld specimens as a function of the shielding gas compositions were obtained from metallurgical microscope with a magnification of $200 \mathrm{X}$ as shown in the Figure 7. The area percents of the various microstructure phases are shown in Table 5.

The parent metal microstructure reveals Ferrite (light phase) Pearlite (darker phase) microstructure as shown in Figure 7(a), which is typically observed in low carbon low alloy steels [6].The pearlite content is estimated to $8 \%$ and the ASTM grain size is 6 to 7 . The microstructure of the welds primarily consists of Polygonal ferrite(PF), Grain boundary ferrite(GF) 

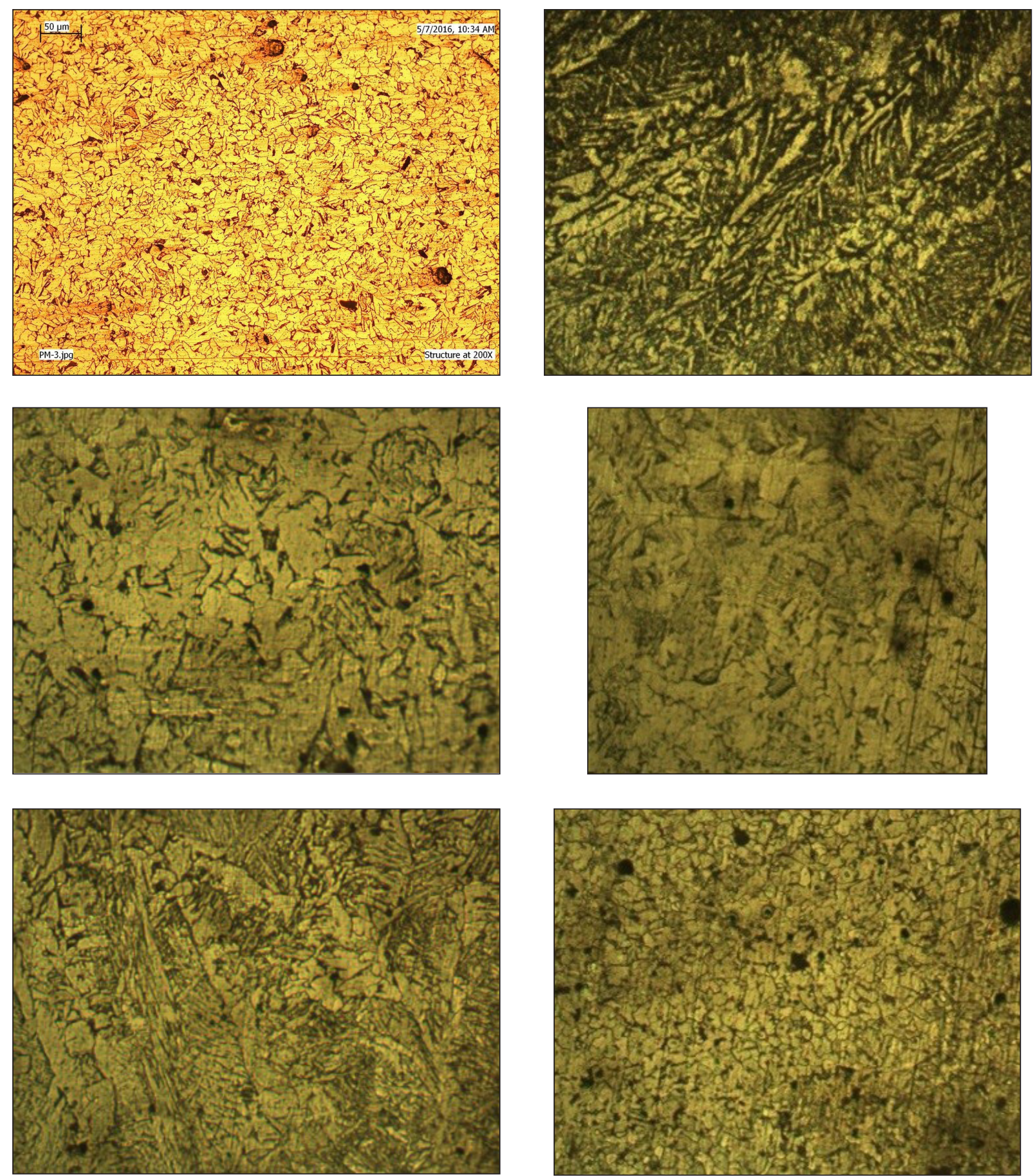

Fig. 7. Microstructure of weld specimens

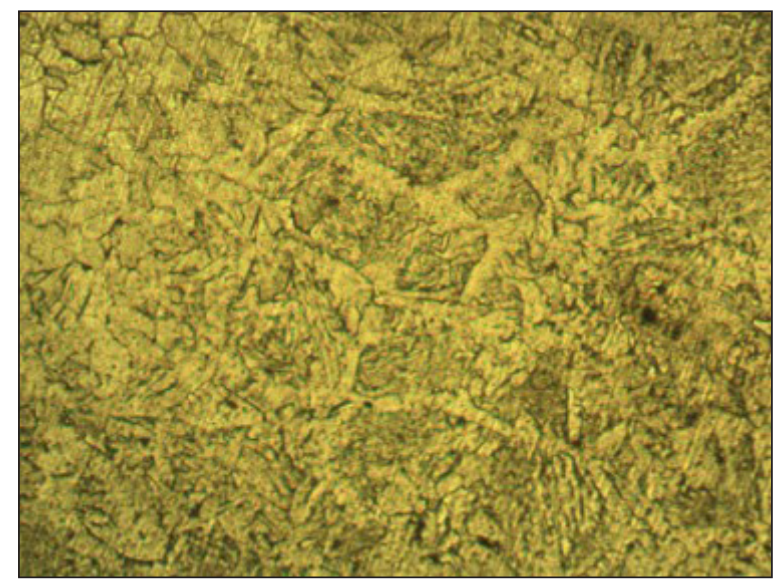

and Acicular ferrite(AF) and also the so-called micro-phases, which include small amounts of martensite, retained austenite or degenerate pearlite. HAZ of specimen 1 (pure $\mathrm{CO}_{2}$ ) consists of coarse ferrite of ASTM size 4 to 5 , Pearlite and carbides $\left(\mathrm{Fe}_{3} \mathrm{C}\right)$ and the Weld metal of specimen 1 consists of high fraction of grain boundary ferrite (GF), polygonal ferrite (PF) and network of pearlite and carbides as shown in Figures 7(b) and 7 (c) respectively. 
Table 5. Microstructure phases of shielding gases used for complete welded joints

\begin{tabular}{|c|c|c|c|}
\hline \multirow{2}{*}{$\begin{array}{c}\text { Shielding gas } \\
\text { composition }\end{array}$} & \multicolumn{3}{|c|}{ Microstructure phases percent } \\
\cline { 2 - 4 } & AF & GF(\%) & $\begin{array}{c}\text { PF and FC } \\
\text { (\%) }\end{array}$ \\
\hline Pure $\mathrm{CO}_{2}$ & 36 & 60 & 4 \\
\hline $80 \% \mathrm{Ar}-20 \% \mathrm{CO}_{2}$ & 56 & 40 & 3 \\
\hline $90 \% \mathrm{Ar}-10 \% \mathrm{CO}_{2}$ & 32 & 28 & 40 \\
\hline
\end{tabular}

It is evident that an increase in $\mathrm{CO}_{2}$ content in the shielding gas in the mixture of gases increases the grain size due to the higher heat input [11].Degree of oxidation is high for pure $\mathrm{CO}_{2}$ and increases with higher quantities of $\mathrm{CO}_{2}$ in the shielding gas and the microstructure of deposited weld metal is a coarse structure. In the cases of specimen $2\left(80 \% \mathrm{Ar}-20 \% \mathrm{CO}_{2}\right)$, the HAZ has dendritic structure with Ferrite, Pearlite and Carbides. The WM microstructure reveals the Pine tree formation of pearlite in the matrix of Ferrite associated with fine Acicular ferrite as shown in Figure 7 (d) and 7(e).The percentage of Acicular Ferrite is found high with less fraction of (GF). In case of specimen $3\left(90 \% \mathrm{Ar}-10 \% \mathrm{CO}_{2}\right)$, the microstructure of HAZ consists of Ferrite and Pearlite but the structure is coarse having ASTM size 4 to 5. The WM consists of high fraction of Polygonal ferrite (PF), Pearlite and carbides. Comparatively larger pearlite of about 3\% segregation is seen as shown in Figure 7(f) and 7(g). Weld metals lean in alloy contents would be expected to transform at relatively high temperatures to produce a microstructure often consisting of ferrite and carbides (FC) having low strength [17] and reduction in Acicular Ferrite (AF).

\section{Effect of the different shielding gas compositions on transverse tensile testing}

The ultimate tensile strength (UTS) of welded joint with $\left(80 \% \mathrm{Ar}-20 \% \mathrm{CO}_{2}\right)$ shielding gas composition exceeded the corresponding value for the investigated base metal [Table 2]; the fracture was in the base metal giving an average value for the UTS of $531 \mathrm{MPa}$. The ultimate tensile strength (UTS) of welded joints with pure $\mathrm{CO}_{2}$ and $(90 \%$ $\mathrm{Ar}-10 \% \mathrm{CO}_{2}$ ) shielding gas compositions were appeared below the UTS of base metal; the fracture was in the welded joint as shown in Table 6. Low UTS for welds with $\left(90 \% \mathrm{Ar}-10 \% \mathrm{CO}_{2}\right)$ shielding gas may be due to segregation of carbide aggregates at HAZ and oxide aggregates in the
Table 6. Effect of the different shielding gas compositions on tensile strength

\begin{tabular}{|c|c|c|}
\hline $\begin{array}{c}\text { Shielding gas } \\
\text { composition }\end{array}$ & $\begin{array}{c}\text { Tensile } \\
\text { Strength } \\
\text { MPa }\end{array}$ & $\begin{array}{c}\text { Point of } \\
\text { Fracture }\end{array}$ \\
\hline $\begin{array}{c}\text { Specimen 1, } \\
\text { Pure } \mathrm{CO}_{2}\end{array}$ & 459.10 & $\begin{array}{c}\text { Weld } \\
\text { metal }\end{array}$ \\
\hline $\begin{array}{c}\text { Specimen } 2, \\
\left(80 \% \mathrm{Ar}-20 \% \mathrm{CO}_{2}\right)\end{array}$ & 531.37 & $\begin{array}{c}\text { Parent } \\
\text { metal }\end{array}$ \\
\hline $\begin{array}{c}\text { Specimen } 3, \\
\left(90 \% \mathrm{Ar}-10 \% \mathrm{CO}_{2}\right)\end{array}$ & 460.89 & $\begin{array}{l}\text { Weld } \\
\text { metal }\end{array}$ \\
\hline
\end{tabular}

WM due to less dilution of the weld pool, which helped for cleavage failure as observed in SEM structure with bright cleavage surfaces in Figure 9 , specimen 3 and the same can be deduced from corresponding EDAS. $\mathrm{CO}_{2}$ is an active gas, react with or burn up some of the alloy from the weld pool in the arc [11], resulting in less recovery of alloy such as Mn by the weld metal from base metal dilution as observed from EDAS for specimen 1 in Figure 9 and the micro structure reveals high fraction of Grain boundary Ferrite. This in turn resulted in a lower weld metal yield and tensile strength for the weld using pure $\mathrm{CO}_{2}$. A combination of good penetration and high fraction of acicular ferrite in microstructure and alloy recovery were obtained because of combination of $\left(80 \% \mathrm{Ar}-20 \% \mathrm{CO}_{2}\right)$ gas resulting in greater strength.

\section{Effect of the different shielding gas compositions on impact toughness test and fracture appearance}

The result of the Charpy impact toughness test conducted at room temperature $(30 \mathrm{C})$ is shown in Figure 8. Generally, the Charpy impact toughness values of WM revealed that as the $\mathrm{CO}_{2}$ percent increases in the shielding gas, the absorbed energy value decreases. This can be attributed to the previous observed microstructures in Figure 7, which

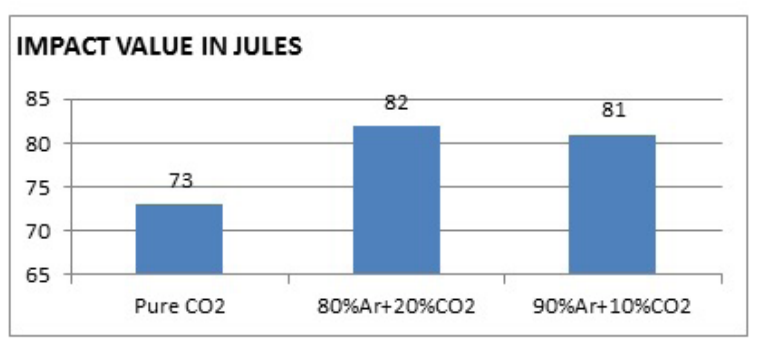

Fig. 8. Average impact energy values of weld metal at room temperature 


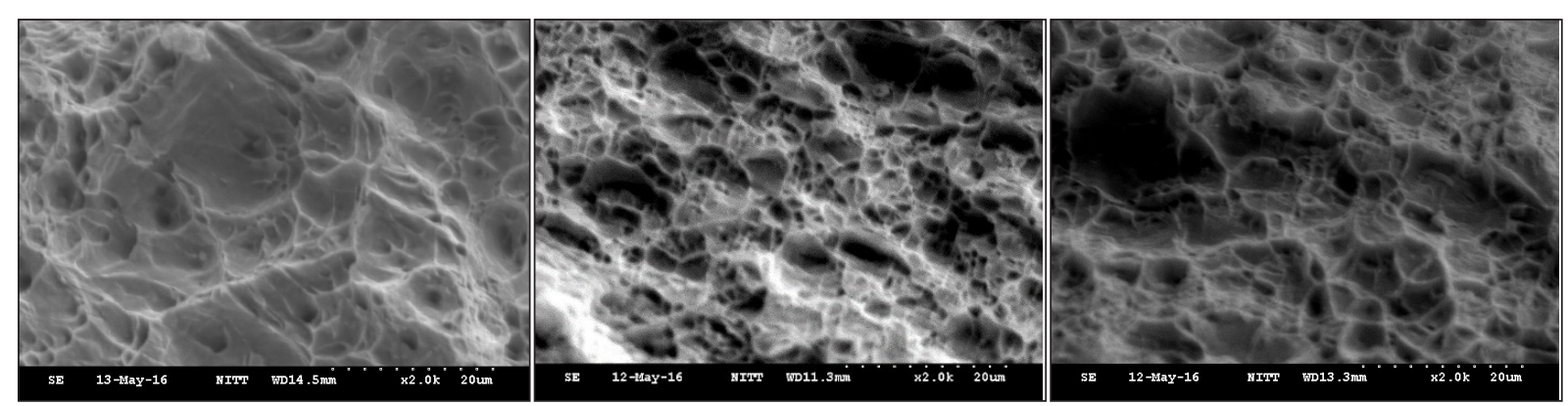

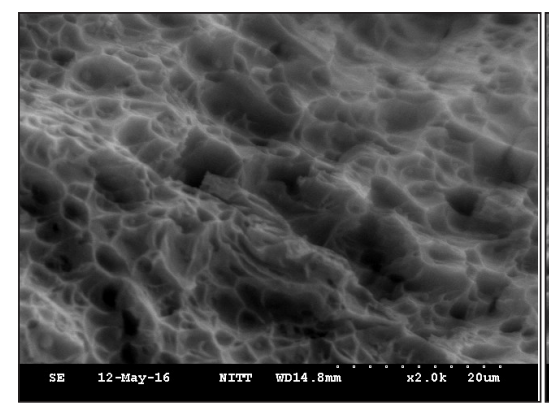

Full scale counts: 1116

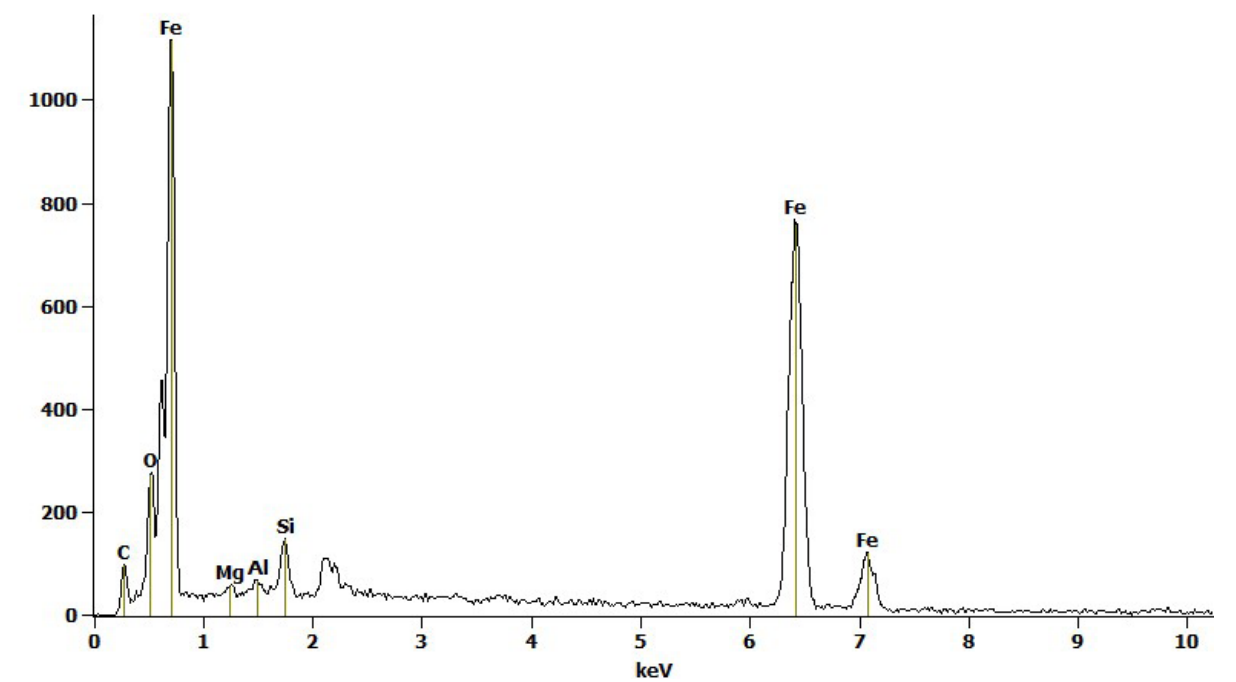

Full scale counts: 937

nitt production(5)

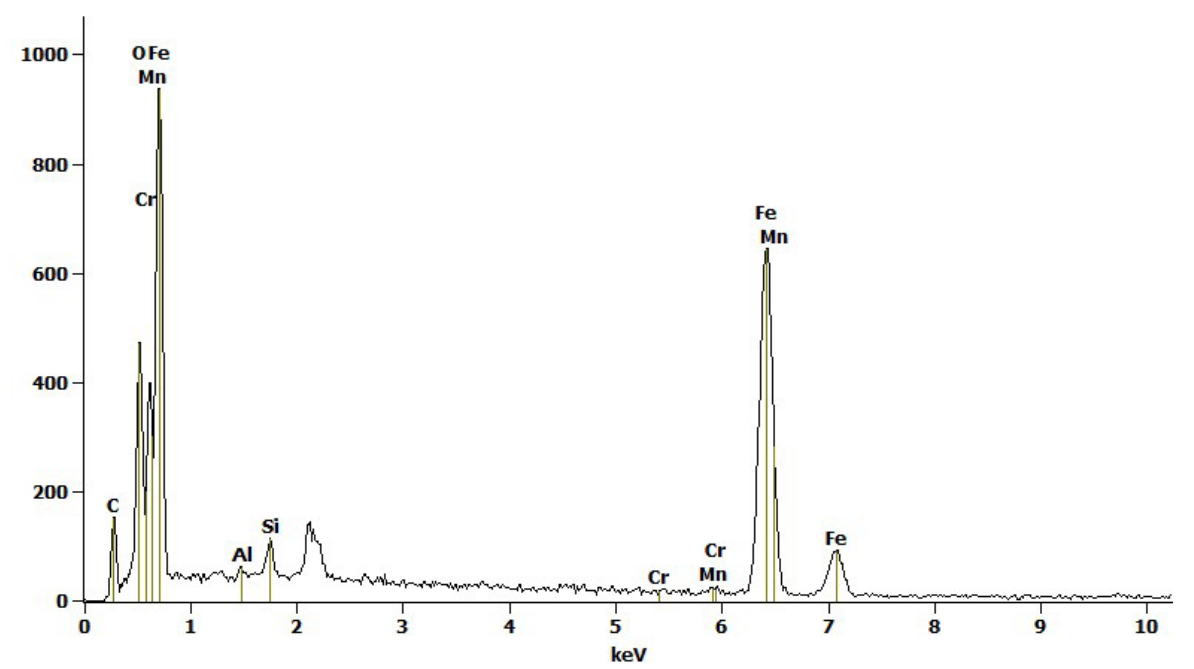

Fig. 9. Fracture appearance figures (1) Pure $\mathrm{CO}_{2}$, (2) $80 \% \mathrm{Ar}-20 \% \mathrm{CO}_{2}$, (3) $90 \% \mathrm{Ar}-10 \% \mathrm{CO}_{2}$

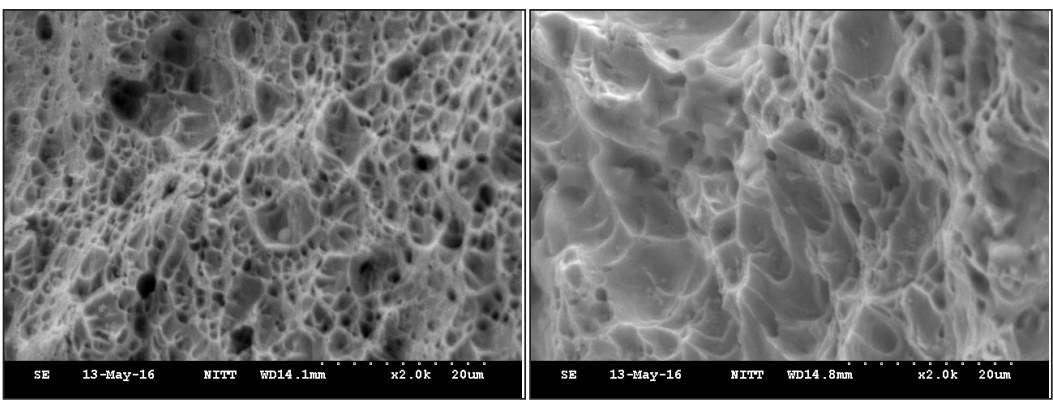

nitt production(5) 
confirmed that Acicular Ferrite percent decreased and Grain boundary Ferrite percent increased with the increase in $\mathrm{CO}_{2}$ content of the shielding gas $[14,18]$. Acicular Ferrite has a beneficial effect on the toughness in the absence of other brittle zones [18]. In the case of $\left(90 \% \mathrm{Ar}-10 \% \mathrm{CO}_{2}\right)$, toughness reduced due to formation of coarser alloy carbides and reduction in Acicular Ferrite as seen from microstructures in Figure 7 (g) and fracture surface of specimen-3 in Figure 9. On increasing silicon content toughness decreases due to the formation of coarser alloy carbides [6].

Scanning electron micrographs of fracture surfaces of Tensile and Charpy impact toughness test specimens in magnification of 2000X are shown in Figure 9 along with EDAS for specific inclusions.

It is clear that the fracture surface morphology for the weld using $\left(80 \% \mathrm{Ar}-20 \% \mathrm{CO}_{2}\right)$ shielding gas is dimple rupture that was recognized by numerous cuplike depressions which are the direct result of the microvoid coalescence, and this shows that the impact fracture surface of weld metal exhibited exclusively ductile fracture and also the parent metal is ductile as seen from tensile fracture surface, as shown in Figure 9, specimen 2. On the other hand, with pure $\mathrm{CO}_{2}$ shielding gas, the resulting fracture surface of weld revealed shiny (cleavage) areas as shown in Fig 9, specimen 1. As mentioned previously in section 5.2, as the $\mathrm{CO}_{2}$ percent in the shielding gas increases; the Grain boundary Ferrite (GF) percent also increases. Accordingly, cleavage cracks propagate more easily in the GF than in Acicular Ferrite (AF). This observation confirms that Acicular Ferrite has a beneficial effect on toughness [18]. In case of $(90 \% \mathrm{Ar}-$ $10 \% \mathrm{CO}_{2}$ ) gas, fracture surface of weld reveals relatively less number of cuplike depressions with oxide inclusions and shiny cleavage areas for crack propagation.

\section{Effect of the different shielding gas compositions on hardness test}

Hardness was measured at several points which represented its distribution along the different areas of weldment. Plots of test positions against hardness values (HV 10) for all the three shielding gases are shown in Figure 10. At HAZ, the microstructure is relatively harder due to the transformation of structure from austenite to pearlite with some martensite caused by heat treatment during welding. Whereas at weldment area, the hardness is relatively low due to overheat treatment received inside the fusion zone. Weld metal hardness decreases with increasing $\mathrm{CO}_{2}$ content in the shielding gas, this may be related to the loss in some alloying elements such as $\mathrm{Mn}, \mathrm{Ni}$ and $\mathrm{Cu}$ during arc welding. The hardness in case of pure $\mathrm{CO}_{2}$ shielding gas showed the lowest values. In case of $\left(90 \% \mathrm{Ar}-10 \% \mathrm{CO}_{2}\right)$ shielding gas, inadequate weld dilution resulted in segregation of inclusion and caused non uniform hardness of weld.

\section{Effect of the different shielding gas compositions on corrosion rate}

Electrochemical polarisation method is preferred for corrosion measurement because it enables the determination of instantaneous reaction rates at electrode or solution interface in a single experiment while other methods require multiple measurements over time to obtain the required corrosion rate data [19]. Further the data generated from such study is broad and can be analysed in many forms thus, serving as the basis for an effective corrosion mitigation.

Samples for Tafel extrapolation study were grounded successively to 1200 grit $\mathrm{SiC}$ abrasive paper and were degreased with acetone. The polarization experiments were conducted in a standard flat cell (Princeton Applied Research,Ametek, USA) in the potential range

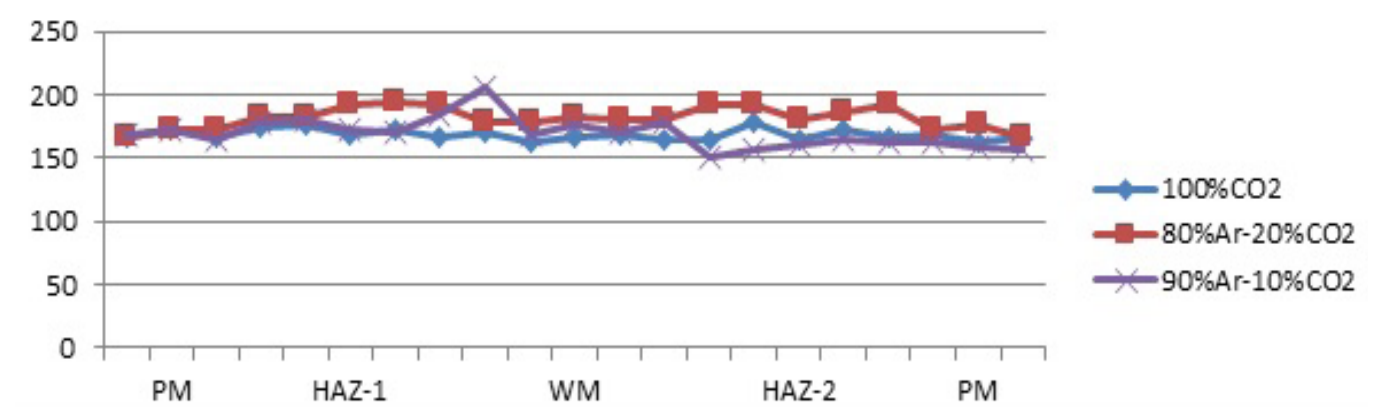

Fig. 10. Hardness results of real welded test pieces 
$-250 \mathrm{mV}$ to $+250 \mathrm{mV}$ versus open circuit potential of samples, using a computer controlled potentiostat (Princeton Applied Research, Ametek273A, USA). $3.5 \% \mathrm{NaCl}$ was used to simulate the immersed corrosion in saline environment [12]. A saturated silver-silver chloride (SSC) reference electrode with platinum counter electrode was used. The scan rate employed for the polarization studies was $0.25 \mathrm{mVs}^{-1}$.

The corrosion current density $\left(\mathrm{i}_{\text {corr }}\right)$ and zero current potential $\left(\mathrm{E}_{\text {corr }}\right)$ were evaluated from Tafel polarization plots by Tafel extrapolation method as per ASTM Standard G3-89 [9,20].Corrosion rate in penetration units, mils/year (mpy) was calculated from $\mathrm{i}_{\text {corr }}$ using the following equation [20]:

$$
\text { mpy }=i_{\text {corr }} \times \Lambda \times \frac{1}{\rho} \times \varepsilon
$$

where: $\Lambda=1.2866 \times 10^{5}$ [equivalents $\left.\cdot \mathrm{sec} \cdot \mathrm{mil}\right] /$

[Coulombs $\cdot \mathrm{cm} \cdot$ years]

$\mathrm{I}_{\text {corr }}$ - the corrosion current density in Amps $/ \mathrm{cm}^{2}(\mathrm{Amp}=1 \mathrm{Coulomb} / \mathrm{sec})$,

$\rho$ - density (7.86 grams $/ \mathrm{cm}^{3}$ for iron),

$\mathcal{E}$ - equivalent weight (27.56 grams/ equivalent, for iron) (According to standard ASTM (G.102-89 of 1999) practice for calculation of corrosion rates and related information from electrochemical measurements, the calculation of equivalent weight $(\varepsilon)$ for alloys entails that only elements above 1 mass percent are included. Hence, in the case of corten steel, iron $(\mathrm{Fe})$ is the only relevant element (see table 1). Equivalent weight is therefore calculated for $\mathrm{Fe}$ only in the equation for calculation of mpy).

The obtained Tafel plots of weld joint specimens and parent metal are shown in Figure 11. The cathodic branch of all Tafel plots exhibit diffusion controlled reaction as corrosion current variations is less and similar. The $\mathrm{NaCl}$ solution used for the potentiostatic Tafel polarization is aerated and neutral where the cathodic reaction consists of the oxygen reduction $\left(\mathrm{O}_{2}+2 \mathrm{H}_{2} \mathrm{O}+\right.$ $4 \mathrm{e} \rightarrow 4 \mathrm{OH}-)$ [6]. This is also evident from Pourbaix diagram of $\mathrm{Fe}-\mathrm{H}_{2} \mathrm{O}$ system [15]. Therefore, as the diffusion controlled oxygen reduction is the only dominant cathodic reaction, the linearity of cathodic Tafel region is absent. The $i_{\text {corr }}$ and corrosion rate (in mpy) obtained from the Tafel polarisation curves of specimens under investigation are tabulated in Table 7.

The corrosion rate is proportional to $i_{\text {corr }}$ and from the table 6 , it can be seen that the specimen1 (pure $\left.\mathrm{CO}_{2}\right)$ and specimen $2\left(80 \% \mathrm{Ar}-20 \% \mathrm{CO}_{2}\right)$ are found to be having lower corrosion potential and the corrosion rate is in the acceptable range when comparing to similar commercial steels [6]. Steel with Acicular ferrite microstructure exhibits the lowest corrosion rate [22].

It is found that the surface of the Acicular ferrite specimen uniformly covered by corrosion products is seemingly denser and more compact as shown in Figure 12, and can provide some amount of protection to the steel; thus the charge transfer resistance and modulus values of the Acicular ferrite specimen are the largest.

However corrosion products on martensite and polygonal ferrite are generally loose, porous, and defective, and can provide minor protectiveness; thus, the charge transfer resistance values for polygonal ferrite and martensite are lower and hence the $i_{\text {corr }}$ value for specimen $3(90 \% \mathrm{Ar}$ $-10 \% \mathrm{CO}_{2}$ ) is higher indicating high corrosion rate and the $i_{\text {corr }}$ value for Specimen $2(80 \% \mathrm{Ar}$ $-20 \% \mathrm{CO}_{2}$ ) is lower indicating better corrosion resistance than the others.

\section{CONCLUSIONS}

The following conclusions are drawn from the experimental results.

Table 7. Corrosion test details

\begin{tabular}{|c|c|c|c|c|}
\hline & Base Metal & $\begin{array}{l}\text { Sample-1 } \\
\text { Pure } \mathrm{CO}_{2}\end{array}$ & $\begin{array}{c}\text { Sample-2 } \\
80 \% \mathrm{Ar}-20 \% \mathrm{CO}_{2}\end{array}$ & $\begin{array}{c}\text { Sample-3 } \\
90 \% \mathrm{Ar}-10 \% \mathrm{CO}_{2}\end{array}$ \\
\hline Corrosion rate $\mathrm{E}(1=0)$ & $-459.136 m V$ & $-442.563 \mathrm{mV}$ & -448.329 & -615.739 \\
\hline$I_{\text {corr }}$ & $-19.05 \mu \mathrm{A}$ & $-20.454 \mu \mathrm{A}$ & $-11.899 \mu \mathrm{A}$ & $-51.817 \mu \mathrm{A}$ \\
\hline Area exposed & $3.0 \mathrm{Cm}^{2}$ & $1.5 \mathrm{Cm}^{2}$ & $1.5 \mathrm{Cm}^{2}$ & $1.5 \mathrm{Cm}^{2}$ \\
\hline $\mathrm{i}_{\text {corr }}=\left(\mathrm{I}_{\text {corr }} /\right.$ area exposed $\left./ 10^{-6}\right)$ & $\begin{array}{c}0.635 \times 10^{-5} \mathrm{~A} \\
/ \mathrm{Cm}^{2}\end{array}$ & $\begin{array}{c}1.36 \times 10^{-5} \mathrm{~A} \\
/ \mathrm{Cm}^{2}\end{array}$ & $\begin{array}{c}0.793 \times 10^{-5} \mathrm{~A} \\
/ \mathrm{Cm}^{2}\end{array}$ & $\begin{array}{c}3.45 \times 10^{-5} \mathrm{~A} \\
/ \mathrm{Cm}^{2}\end{array}$ \\
\hline Corrosion rate (mpy) & 2.86 & 6.15 & 3.5 & 15.5 \\
\hline
\end{tabular}



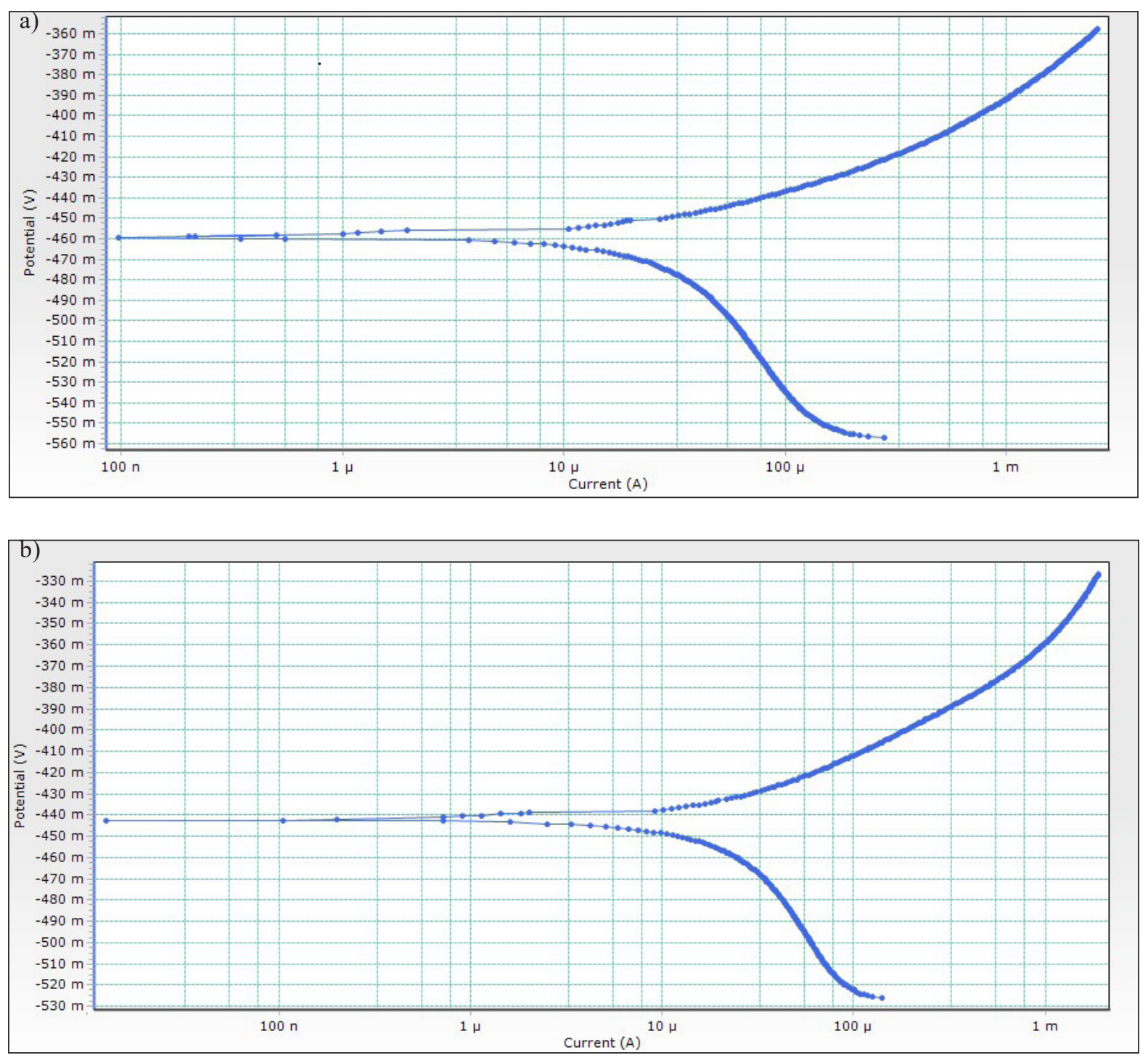

c)

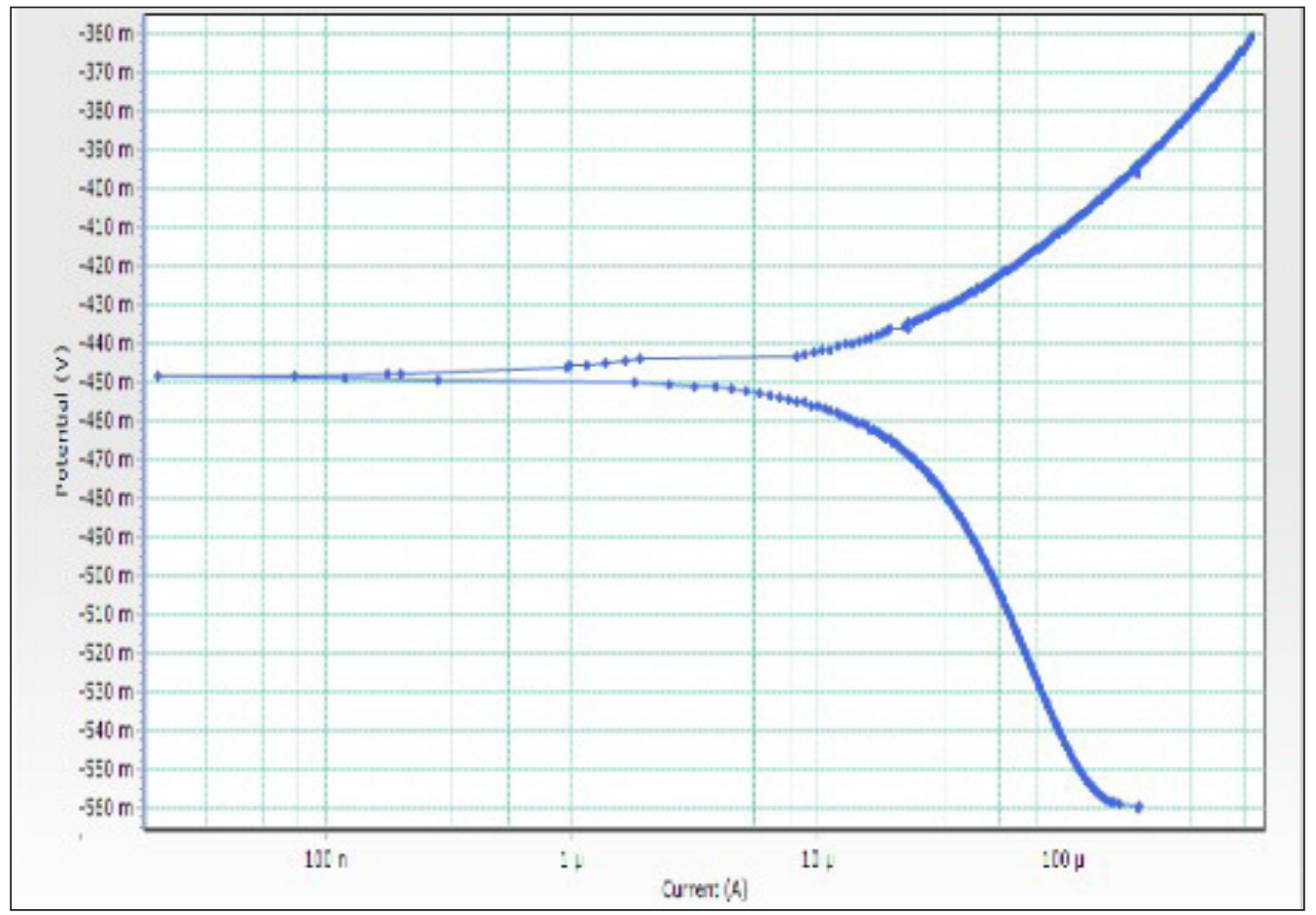




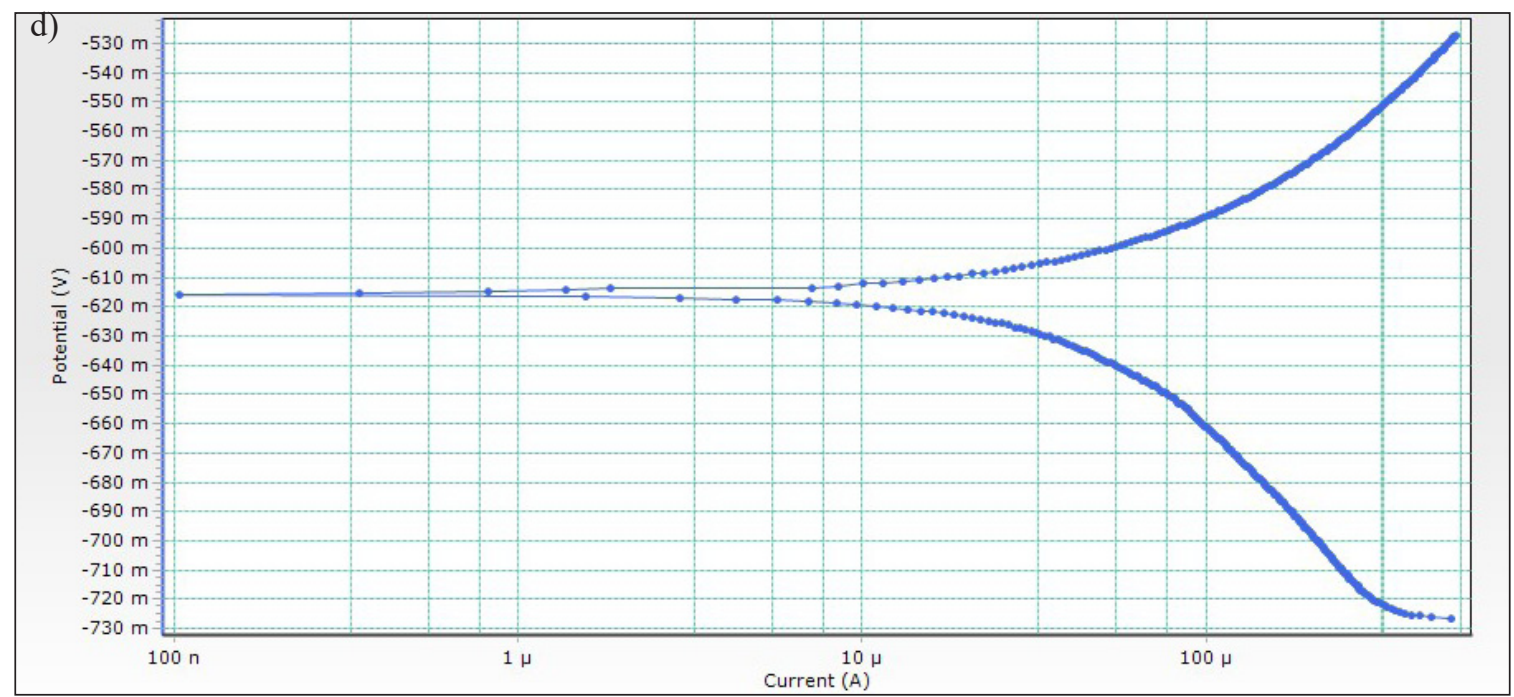

Fig. 11. Tafel plots of weld joint specimens and parent metal

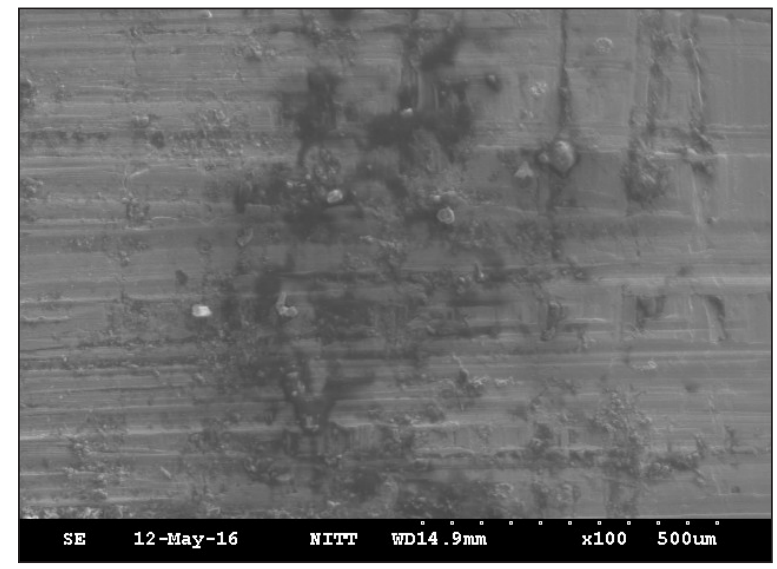

Fig. 12. SEM of surface of specimen-2(80\% $\mathrm{Ar}-$ $20 \% \mathrm{CO} 2$ ) after corrosion test

1. The shielding gas compositions have great effect on the cooling rate due to the ionization potential of each shielding gas that governs producing high or low HI. Cooling rate of shielding gas with high percentage of Argon (Ar) content such as $90 \% \mathrm{Ar}$ and above was faster than that of other shielding gas composition has resulted in microsegregation within individual weld beads due to segregation of major and trace elements during solidification.

2. The Weld Metal macrostructure of corten steel weld using ( $\left.80 \% \mathrm{Ar}-20 \% \mathrm{CO}_{2}\right)$ shielding gas shows good penetration, uniform side wall fusion and uniform weld bead and the microstructure has formation of a high amount of Acicular Ferrite which leads to the improvement of strength \& toughness.
3. The corrosion resistance is found increasing with Acicular Ferrite due to adherent protective layer formed over the surface, which protects the surface from corrosive environment.

4. The study shows that Acicular Ferrite gives the steel strength, toughness and corrosion resistance, whereas Polygonal Ferrite, Grain boundary Ferrite, other micro phases and micro segregations reduce the strength.

5. Increasing the amount of $\mathrm{CO}_{2}$ in the shielding gas decreases the hardness of Weld Metal and may be related to losses in some alloying elements such as Mn and Si resulting in decrease of Acicular Ferrite content. The area percent of Grain boundary Ferrite is higher than that of Acicular Ferrite indicates that the cooling rate is slow in case of pure $\mathrm{CO}_{2}$ shielding gas.

6. As the $\mathrm{CO}_{2}$ percent in the shielding gas increases, the required absorbed energy (impact toughness) of Weld Metal decreases due to the decrease of the amount of Acicular Ferrite.

7. Among the investigated shielding gas combinations, keeping the parameters constant, the weld using shielding gas composition of $(80 \%$ $\mathrm{Ar}-20 \% \mathrm{CO}_{2}$ ) has achieved better Mechanical, metallurgical and corrosion properties.

\section{Acknowledgements}

Authors are thankful to the Chief Workshop Manager, Central Workshop, Southern railway, Trichy for sponsoring for the M.S. (By research) programme and providing the necessary support to carry out this research work. And also thank- 
ful to Dy. Chief Mechanical Engineer (C\&W), Central Workshop, Southern Railways for giving guidance throughout the research work. Author is also thankful to Prof. S. Natarajan, Chairman CECASE, National Institute of Technology Trichy for his support and motivations.

\section{REFERENCES}

1. American Society for Mechanical Engineers. ASME SFA 5.32 Specification for welding shielding gases, 2007.

2. American Society for Mechanical Engineers. Boiler and pressure vessel code - qualification standard of welding and brazing procedures, welders, brazers, and welding and brazing operators, 2007.

3. American Welding Society. Requirements for impact testing, 2004.

4. ASM international. Basic understanding of weld corrosion, 2006.

5. Ebrahimnia M., Goodarzi M., Nouri M. and Sheikhi M. Study of the effect of shielding gas composition on the mechanical weld properties of steel St. 37-2 in gas metal arc welding, Materials and Design, 30, 2009, 3891-3895.

6. Sahoo G., Deva A., Singh B. and Sexena A. Corrosion behaviour of high phosphorus containing $\mathrm{Cu}-\mathrm{Cr}$ weather resistant steel. Journal of Metals, Materials and Minerals, 24(2), 2014, 1-8.

7. Gertsovich and Svanberg N. Analysis of MIG welding with aim on quality, M.Sc. Thesis, Dept. Signal Processing, Blekinge Institute, Sweden, 2008.

8. Govt. of India., Ministry of Railways. Guidelines for Corrosion Repair in ICF coaches, 2013.

9. Ijsseling F.P. Application of electrochemical methods of corrosion rate determination to system involving corrosion product layers. Br. Corros. J., 21(2), 1986, 95-101.

10. Indian Railways. Specification IRS-M41-1997.

11. Boiko I. and Avisans D. Study of shielding gases for MAG welding, Materials Physics and Mechanics, Riga Technical University, Latvia, 16, 2013, 126-134.

12. Möller H., Boshoff E.T. and Froneman H. The corrosion behaviour of a low carbon steel in natural and synthetic seawaters. The Journal of The South African Institute of Mining and Metallurgy, 106, 2006, 585-592.

13. Morcillo M., Díaz I., Chico B., Cano H. and de la Fuente D. Weathering steels: from empirical development to scientific design. A review. Corrosion Science, 83, 2014, 6-31.

14. Mukhopadhyay S. and Pal T.K. Effect of shielding gas mixture on gas metal arc welding of HSLA steel using solid and flux-cored wires. International Journal of Advanced Manufacturing Technology, 29, 2005, 262-268.

15. Pourbaix M. and Zoubov N.D. Establishment and interpretation of Potential-pH Equilibrium Diagrams. Atlas of Electrochemical Equilibria in Aqueous Solutions, second English Ed., 1974, 307-342.

16. Prinston Applied Research. Application Note CORR-1, Basic corrosion measurements.

17. Ramrez J.E. Characterisation of high-strength steel weld metals: chemical composition. microstructure and nonmetallic inclusions. Welding Journal, 87, 2008, 65-75.

18. Gadallah R., Fahmy R., Khalifa T. and Sadek A. Influence of shielding gas composition on the properties of flux-cored arc welds of plain carbon steel. International Journal of Engineering and Technology Innovation, 2(1), 2012, 1-12.

19. Sekunowo O.I., Adeosun S.O. and Lawal G.I. Potentiostatic polarisation responses of mild steel in seawater and acid environments. International Journal of Scientific and Technology Research, 2(10), 2013, 139-145.

20. Tait W.S. An Introduction to Electrochemical Corrosion Testing for Practicing Engineers and Scientists. Wisconsin, Pair O’ Docs., 1994.

21. Yamashita M., Miyukia H., Matsudaa Y.,Naganoa H. and Misawa T. The long term growth of the protective rust layer formed on weathering steel by atmospheric corrosion during a quarter of a century. Corros. Sci. 36(2), 1994, 283-299.

22. Guo Y-B., Li C., Liu Y-C., Yu L-M., Ma Z-Q., Lin $\mathrm{C}-\mathrm{X}$. and $\mathrm{Li} \mathrm{H}$. Effect of microstructure variation on the corrosion behaviour of high strength low alloy steel in $3.5 \mathrm{wt} \% \mathrm{NaCl}$ solution. International Journal of Minerals, Metallurgy and Materials, 22(6), 2015, 604-612. 